\title{
FIRE AND VEGETATION HISTORY OF THE LAST 2000 YEARS IN JACKSON HOLE, WYOMING
}

\section{CATHY WHITLOCK $\downarrow$ KAREN JACOBS $\downarrow$ DEPARTMENT OF EARTH SCIENCES MONTANA STATE UNIVERSITY $\downarrow$ BOZEMAN}

\section{$-\quad$ INTRODUCTION}

Fire is an important form of natural disturbance in nearly all terrestrial ecosystems in the western United States, and it serves as a critical link between climate change and ecosystem response (Agee, 1990; Swetnam and Betancourt, 1998). The nature of these linkages depends on the time scale of interest. On short time scales, climate/weather and vegetation characteristics affect the fire conditions of particular years (and decades), as well as the dynamics of post-fire ecological succession. On centennial and millennial time scales, large-scale changes in climate alter regional fire regimes and vegetation composition. The linkages are especially complex in the western U.S., where fire regimes vary across environmental gradients and include frequent surface fires as well as infrequent stand-replacement events.

Fire-history information is obtained from two complementary data sets: tree-ring records and lake-sediment charcoal records. Tree-ring records are spatially precise but temporally limited by the age of living trees and subfossil wood (Arno and Sneck, 1977; Johnson and Gutsell, 1994; Baker and Ehle, 2001). Charcoal records, obtained from the sediments of natural lakes and wetlands, span a much longer time and are associated with pollen records that provide information on the vegetation history of an area (Whitlock and Larsen, 2001). Most charcoalbased fire-history studies have been conducted in middle- and high-elevation forest ecosystems, where natural lakes are abundant. While our understanding of past fire regimes in these relatively mesic ecosystems is improving, we have almost no information on the long-term fire history of lowelevation forest and steppe, despite the fact that these ecosystems are especially sensitive to drought and land-use activities (Swetnam, 2002; McKenzie et al., 2004).

The last 2000 years of environmental history is of particular interest because it encompasses both human-induced and natural environmental change. In Grand Teton National Park (GTNP), displacement of Native Americans and their burning activities, as well as the impacts of Euro-American trappers, miners and homesteaders likely resulted in changes in vegetation and fire regime (Daugherty, 1999). Land management practices, including fire suppression, in the $20^{\text {th }}$ century, have also shaped the composition and structure of forests and possibly steppe communities. Climate variations, such as the Medieval Climate Anomaly (ca. $1100-500$ cal yr BP; Hughes and Diaz, 1994) and the Little Ice Age (ca. 450 - 50 cal yr BP; Bradley, 1999; Cook et al., 1999), have altered fire regimes and vegetation in GTNP, which in turn would have influenced human activities and impacts. Thus, land use, land management, climate, and fire have helped create the modern low-elevation ecosystems in the Grand Teton National Park, but the interactions among these variables are poorly understood.

Jackson Hole at the foot of the Teton Range is exceptional in the western U.S. in having a number of natural lakes in low-elevation settings suitable for 
paleoecologic research. To fill in the gap in our understanding of low-elevation ecosystems, we are developing a fire and vegetation history of the last 2000 years at three lake sites located in the dry forest and steppe communities of GTNP. Our sites are Hedrick Pond (lat. $43.73^{\circ} \mathrm{N}$, long. $110.59^{\circ} \mathrm{W}$, elev. $2048 \mathrm{~m}$ ), Pothole Lake (lat. $43.78^{\circ} \mathrm{N}$, long. $110.62^{\circ} \mathrm{W}$, elev. $2033 \mathrm{~m}$ ) and Swan Lake (lat. $43.89^{\circ} \mathrm{N}$, long. $110.63^{\circ} \mathrm{W}$, elev. $2072 \mathrm{~m}$ ) (Fig. 1). Swan Lake is farthest north in the valley and surrounded by lodgepole pine forest. It is separated from Pothole Lake and Hedrick Pond by the Snake River and the southern end of Jackson Lake. Hedrick Pond lies at the ecotone between lodgepole pine and Douglas-fir forest to the south and east and sagebrush steppe to the west. Pothole Lake is located in sagebrush steppe in the middle of the valley; it is separated from Hedrick Pond by the Snake River.

Our objective is to examine the fire history in closely spaced sites to identify spatial and temporal patterns in the fire regime that might be related to human-induced or natural environmental change. Pollen data from lake-sediment cores provide information on vegetation changes, and charcoal records are used to develop a local fire history. Changes in lithology help assess variations in sediment input that might be related to shifts in lake production and watershed inputs. A chronology upon which to build the environmental history comes from radiometric dating of organic and core material. This investigation of Jackson Hole's history is part of a larger research effort to understand the Holocene vegetation, climate, and fire history of Greater Yellowstone Ecosystem (e.g. Whitlock, 1993; Whitlock and Bartlein, 1993; Whitlock et al., 1995; Millspaugh et al., 2004; Whitlock et al., 2006).

\section{$\downarrow$ METHODS}

Sediment cores were collected from the three study lakes (Fig. 1). Cores were taken in the deepest part of the lakes from a floating platform constructed across two inflatable boats. Cores were obtained with a 5-cm-diameter Livingstone piston sampler, which retrieves meter-long cores, and a 7$\mathrm{cm}$-diameter short corer that recovers the mud-water interface and uppermost sediments. Cores were extruded in the field, wrapped in cellophane and aluminum foil, and transported back to the MSU Paleoecology Lab for study.

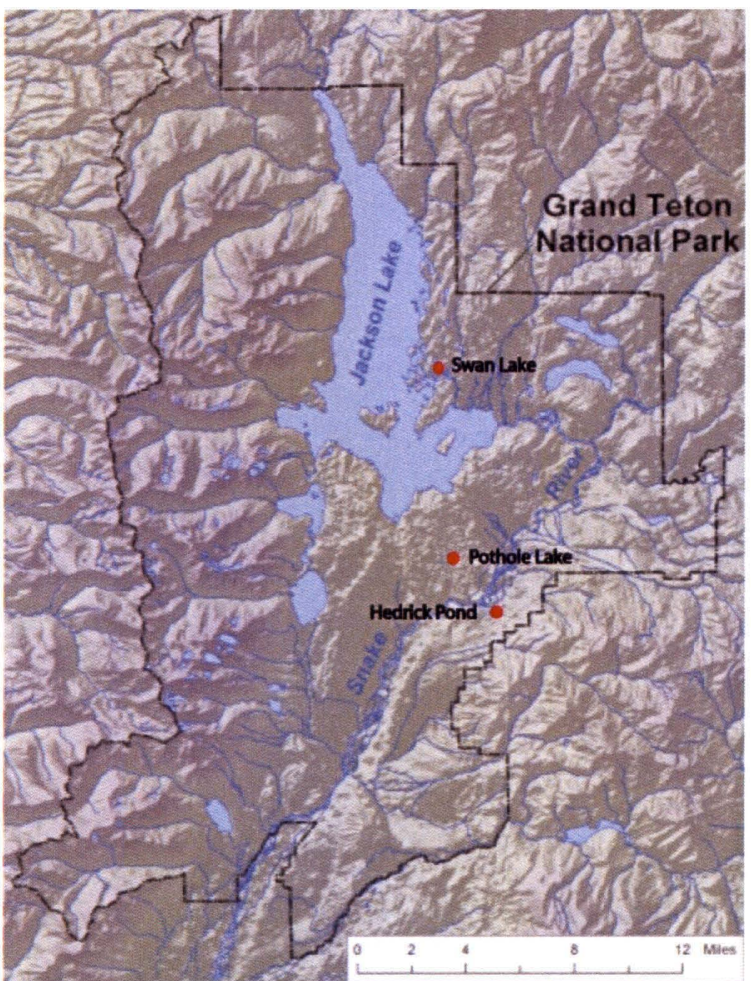

Figure 1: Map of Grand Teton National Park showing location of study sites.

Cores were split longitudinally for lithologic descriptions and subsampling. Changes in sediment color, composition, and lithology were described. One- $\mathrm{cm}^{3}$ samples were dried at $90^{\circ} \mathrm{C}$, and then ashed at $550^{\circ} \mathrm{C}$, and $900^{\circ} \mathrm{C}$. Weight loss after each heating was used to calculate percentages of dry weight, organic content, and carbonate content, respectively (Dean 1974). Magnetic susceptibility, an indicator of erosion of mineral soil or fire-created magnetite or maghemite (Thompson and Oldfield, 1986), was measured with a Bartington MS2 magnetic susceptibility machine. MS units were expressed as cgs $\times 10^{-6}$.

A chronology for each lake was based on a series of ${ }^{210} \mathrm{~Pb}$ dates on sediment and $\mathrm{AMS}{ }^{14} \mathrm{C}$ dates obtained from terrestrial plant macrofossils. Radiocarbon ages were converted to calendar years, using the CALIB program of Stuiver et al. (2005). Age-depth models were developed for each site and used to describe the sedimentation rates (Fig. 2). 


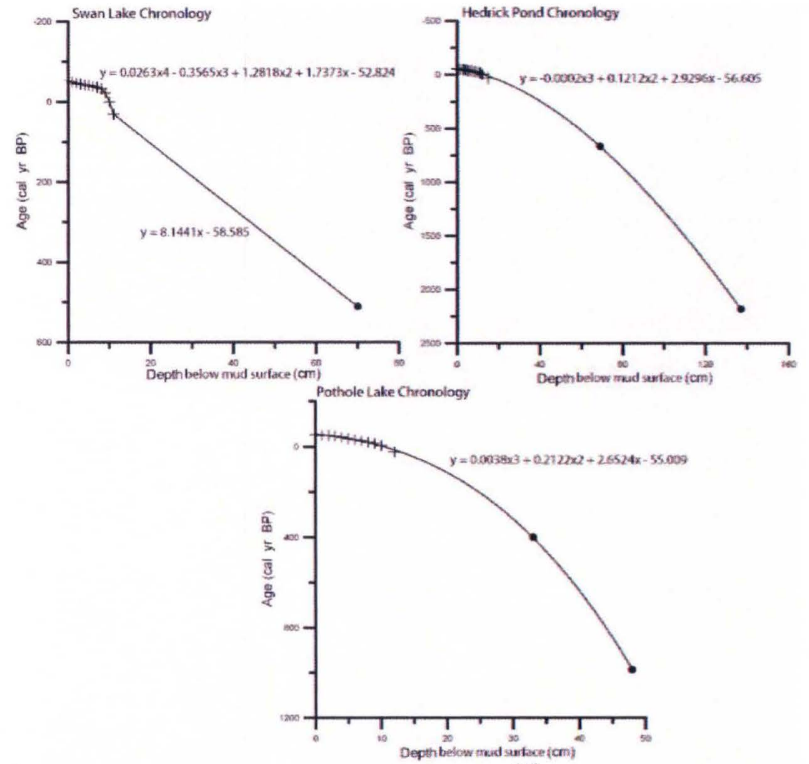

Figure 2: Age versus depth models based on ${ }^{210} \mathrm{~Pb}$ (shown as + ) and calibrated ${ }^{14} \mathrm{C}$ dates (shown as $\bullet$ ) for Swan Lake, Hedrick Pond and Pothole Lake. The Swan Lake chronology uses two different age models, one based on ${ }^{210} \mathrm{~Pb}$ dates and the other based on the last ${ }^{210} \mathrm{~Pb}$ date and the ${ }^{14} \mathrm{C}$ date. Other age models incorporate all dates.

Macroscopic charcoal analysis was performed on contiguous $1-\mathrm{cm}$ interval samples to reconstruct the local fire history for each site (e.g. Long et al., 1998). Samples of $3 \mathrm{~cm}^{3}$ (Hedrick Pond and Swan Lake) and $4 \mathrm{~cm}^{3}$ (Pothole Lake) were soaked in a $5 \%$ solution of sodium metaphosphate and $6 \%$ bleach for 24 hours and washed through nested sieves (mesh size 250 and $125 \mu$ ). Residues were placed in a gridded Petri dish and identified under a stereoscope at magnifications of $120 \mathrm{x}$ and 250x. Charcoal abundance was calculated as charcoal concentration (particles $/ \mathrm{cm}^{3}$ ), and these data were converted to charcoal accumulation rates (CHAR; particles $/ \mathrm{cm}^{2} /$ year) by multiplying charcoal concentration by sedimentation rate ( $\mathrm{cm} /$ year).

The development of a fire history from the charcoal data followed the approach of Long et al. (1998). Time series of CHAR data were divided into two components. Background CHAR, or the lowfrequency slowly varying component, was determined using a locally-weighted (moving) average through the time series. Variations in background CHAR represent changes in regional fire activity, charcoal stored in the watershed, or changes in the biomass of the surrounding area (Long et al., 1998; Whitlock and Larsen, 2001; Marlon et al., in press). For all sites in this study, a window width of 500 years was used to calculate background CHAR levels. This window width has become a standard for Greater Yellowstone area charcoal studies, and it produced a background signal that followed the broad frequency trends in the data (Marlon et al., in press). Peaks, or the high-frequency component, were identified as those levels that exceeded a prescribed threshold ratio of total CHAR to background CHAR. Charcoal peaks were inferred to be fire episodes (one or more fires per sample). A threshold ratio of 1.0, for example, identifies all CHAR values that exceed the background CHAR level as fire episodes. A fire event begins when the threshold ratio is first exceeded and ends when CHAR values drop below the ratio. A threshold ratio of 1.15 was used in this study, because it produced charcoal peaks that corresponded in time with recent fires in the vicinity of each site (Loope, 1974). The ratio did not pick up additional spurious peaks that were not associated with local fire (Figure 3).

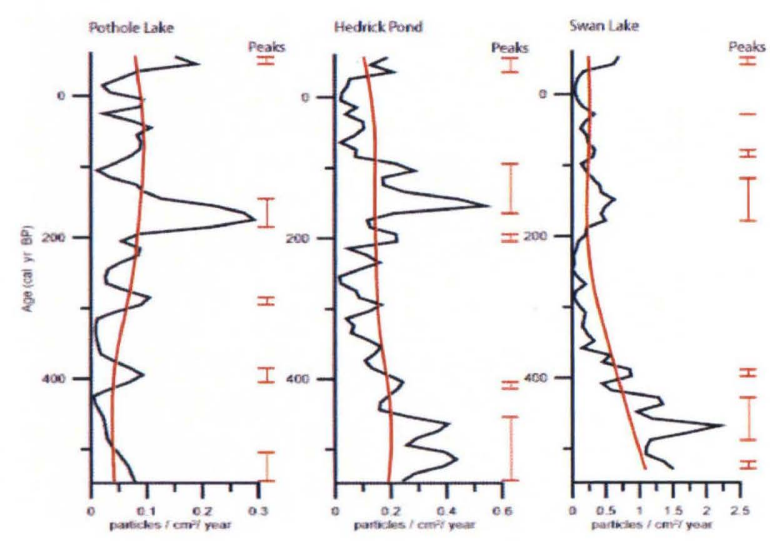

Figure 3: Fire reconstructions for Hedrick Pond, Pothole Lake and Swan Lake for the last $550 \mathrm{cal} \mathrm{yr} \mathrm{BP.} \mathrm{Red} \mathrm{line} \mathrm{are} \mathrm{charcoal}$ accumulation rates (CHAR; particles $/ \mathrm{cm}^{2} /$ year); black line is background CHAR calculated using a weighted window width of 500 years. Red bars mark fire episodes and begin when CHAR values exceed background CHAR level by a threshold ratio of 1.15 .

Pollen samples were taken at regularly spaced intervals (approximately 30 -year intervals) in each core and processed following the methods of Faegri et al. (1989). Pollen slides were counted under a microscope at 400x magnification. Common pollen types identified in the Jackson Hole area include Pinus contorta type (diploxylon-type Pinus), Artemisia spp., and Picea spp. Percentage data of terrestrial taxa were tallied based on the sum of all terrestrial taxa. Percentage of aquatic taxa was based on the sum of all taxa. A "spike" of Lycopodium spores of known concentration was added to each sample to calculate pollen concentration. Concentration data was multiplied by the sedimentation rate of each sample to calculate pollen accumulation rates (pollen/ $/ \mathrm{cm}^{2} /$ year). Pollen work is ongoing and not presented in this report 


\section{PRELIMINARY RESUlts}

A 137-cm-long core was obtained from Hedrick Pond. The sediments consisted of homogeneous fine detritus gyttja, and the age-depth model suggested that core spanned the last $2100 \mathrm{cal}$ yr BP. [Note: "cal yr BP" means calendar years before present with "present" set at AD 1950.] A 70cm-long core from Pothole Lake consisted of an upper unit of fine detritus gyttja that graded downward into silty detritus gyttja $(17-50 \mathrm{~cm})$ and dry organic silty clay at the base. The bottom unit at $66 \mathrm{~cm}$ depth had a crumbly structure with fine rootlets and appeared to be a soil. Extrapolation from the lowest radiocarbon age at Pothole Lake suggests the existence of a lake environment for the last 2100 cal yr. A core from Swan Lake consists of fine detritus gyttja from $0-13 \mathrm{~cm}$ depth that was underlain by gray-brown clay from $13-47 \mathrm{~cm}$ depth, and dark brown mud with root fragments from $47-57 \mathrm{~cm}$ depth. A radiocarbon age from the mud unit had an age of $550 \mathrm{cal}$ yr BP.

The Swan Lake charcoal record had a sampling resolution of about 9.6 years $/ \mathrm{cm}$. Background CHAR levels from 550 to $200 \mathrm{cal}$ yr BP were $\sim 1$ particle $/ \mathrm{cm}^{2} /$ year, and they decreased to $\sim$ 0.3 particles $/ \mathrm{cm}^{2} /$ year in the last $200 \mathrm{cal} \mathrm{yr}$. Peaks were identified at ca. $-30,40,100,120-190,400$, $430-490$, and $550 \mathrm{cal} \mathrm{yr} \mathrm{BP}$, and these are assumed to represent decades of local fire activity.

The resolution of the Hedrick Pond charcoal record is about 17.5 years $/ \mathrm{cm}$. Background CHAR was $\sim 0.2$ particles $/ \mathrm{cm}^{2} /$ year between 2150 and 1500 cal yr BP, and decreased to $\sim 0.13 \mathrm{particles} / \mathrm{cm}^{2} /$ year in the interval between 1500 and 750 cal yr BP. Background charcoal levels increased in the last 750 cal yr BP to $\sim 0.2$ particles $/ \mathrm{cm}^{2} /$ year. Peaks occurred at ca. $-30,100-180,200,400,560,950,1060,1200$, $1430,1650,1750,2000$, and 2130 cal yr BP.

At Pothole Lake, the deposition time of each sample was about 27.2 years $/ \mathrm{cm}$. The background charcoal was low $\sim 0.04$ particles $/ \mathrm{cm}^{2} /$ year from 2100 to 1250 cal $\mathrm{yr} \mathrm{BP}$, and increased to $\sim 0.1$ particles $/ \mathrm{cm}^{2} /$ year from 1250 to present. Peaks occurred in ca, -30, 140-190, 300, 400, 560, 700, 950, $1200,1430,1650,1950$, and 2130 cal yr BP.

\section{Discussion}

\section{The last 550 years}

Swan Lake, Hedrick Pond and Pothole Lake have concurrent charcoal peaks that suggest periods of widespread fires in -30 cal yr BP (AD 1980), 140180 cal yr BP (AD 1810-1770), and 400 cal yr BP (AD 1550) (Fig. 3). Swan Lake also contains charcoal peaks at $40 \mathrm{cal} \mathrm{yr} \mathrm{BP} \mathrm{(AD} \mathrm{1910)} \mathrm{and} 100 \mathrm{cal}$ yr BP (AD 1850) that were not noted at the other sites. About $175 \mathrm{cal} \mathrm{yr} \mathrm{BP} \mathrm{(AD} \mathrm{1775)} \mathrm{and} 400 \mathrm{cal} \mathrm{yr}$ $\mathrm{BP}$ (AD 1550), fires occurred close enough to each of the three sites to be registered in their charcoal records. Tree-rings record large fires in Jackson Hole about 190 cal yr BP (AD 1760), and these are likely the source of charcoal in the study sites (Loope, 1974).

Background levels of CHAR provide information on past levels of burning and the amount of charcoal produced during fire (Long et al., 1998). Swan Lake showed a decrease in background CHAR from $\sim 1$ particle $/ \mathrm{cm}^{2} /$ year to $\sim 0.3$ particles $/ \mathrm{cm}^{2} /$ year at about 500 cal yr BP (AD 1400). The period of decreasing background CHAR at Swan Lake coincided with the beginning of cooler/moister conditions during the Little Ice Age. It may be that this shift in fire regime reflects the development of lodgepole pine forest at Swan Lake and a reduction in available fuels compared to the previous period. Conversely, at 500 cal yr BP (AD 1450), Pothole Lake in sagebrush steppe shows a slight increase in background CHAR, which suggests that sagebrush might have been burning more than forests at this time. Background CHAR levels at Hedrick Pond remained fairly constant over the last 550 cal years, implying no appreciable change in biomass over this time.

Trappers and fur-traders arrived in Jackson Hole in the mid-1700s (200 cal yr BP), and miners were present in the valley in the mid-1800s $(100 \mathrm{cal}$ yr BP) (Daugherty, 1999). A fire episode recorded at Hedrick Pond, Pothole Lake and Swan Lake at about 175 cal yr BP (AD 1775) corresponds with the arrival of trappers to the valley, and fires at this time may have been human-set. Miners were present in the Pilgrim Creek drainage in the mid-1800s (100 cal yr BP) (Daugherty, 1999) and may have been responsible for the fire registered at nearby Swan Lake at that time. About -30 cal yr BP (AD 1980), fires occurred in Jackson Hole and around the valley margins. Large fires in Yellowstone in 1988 may have contributed some long-distance charcoal to the sites in Jackson Hole along with the charcoal from local fires.

\section{The last 2100 years}

Hedrick Pond and Pothole Lake have 
charcoal peaks that indicate fire episodes at $560 \mathrm{cal}$ yr BP (AD 1390), $950 \mathrm{cal} \mathrm{yr} \mathrm{BP} \mathrm{(AD} \mathrm{1000),} 1180 \mathrm{cal}$ yr BP (AD 770), 1430 cal yr BP (AD 520), $1650 \mathrm{cal}$ yr BP (AD 300), and 2130 cal yr BP (BC 130), as well as those during the last 550 years discussed above (Figure 4). The co-occurrence of charcoal peaks suggests times when one or several fires occurred in Jackson Hole, burning both forest and steppe.

Background levels of charcoal were fairly constant in the Hedrick Pond record with the exception of a slight dip from $\sim 0.2$ to $\sim 0.1$ particles $/ \mathrm{cm}^{2} /$ year between 1500 and $750 \mathrm{cal} \mathrm{yr}$ BP (AD 1200). The amount of charcoal produced during fires was reduced at this time. At Pothole Lake, background CHAR rose from $\sim 0.05$ to 0.08 particles $/ \mathrm{cm}^{2} /$ year at $1300 \mathrm{cal} \mathrm{yr}$ BP (AD 650) and fell to $\sim 0.05$ particles $/ \mathrm{cm}^{2} /$ year at $600 \mathrm{cal}$ yr BP (AD 1350). These changes in background charcoal coincide with the Medieval Climate Anomaly (ca. $1100-500$ cal yr BP, AD 850 - 1450; Hughes and Diaz, 1994; Cook et al., 1999), when the Greater Yellowstone region experienced drought (Meyer et al., 1995). The rise in background CHAR at Pothole Lake suggests more severe, charcoal-producing events in steppe environments. In contrast, woody fuels at Hedrick Pond may have limited fire severity during this period.

Native Americans have inhabited Jackson Hole for approximately 9000 years before the arrival of Euro-Americans (Connor, 1998), with the oldest archeological records dated by the type of projectile point. Patterns of artifact assemblages throughout the valley suggest that seasonal occupation changed over time, and specifically within the last 2000 cal years. Native Americans used the northern portion of the valley in the late summer and fall between 2000 and 800 cal yr BP (AD 0 - 1150). Between 800 and 200 cal yr BP (AD 1150 - 1750), Native Americans used more sites in southern Jackson Hole during the spring and summer months (Connor, 1998). Although seasonal patterns of occupation changed within the last 2000 years, the charcoal records offer no evidence that these changes were accompanied by heightened burning activities on the part of Native peoples.

\section{$\uparrow$ CONCLUSION}

The results of our study document periods of heightened fire activity during the last two millennia. The widespread fires in the 1980s, which included burning in Jackson Hole, are evidenced in the charcoal records of all three low-elevation sites. Similar fire episodes are recorded throughout the last 2100 years. Most recently, Euro-American activity coincides with fire episodes around $100 \mathrm{cal} \mathrm{yr}$ BP (AD 1850) and $175 \mathrm{cal} \mathrm{yr} \mathrm{BP} \mathrm{(AD} \mathrm{1775).} \mathrm{These} \mathrm{fire}$ periods are also registered in the tree-ring record. Although it is impossible to determine the exact cause of past fires, there is no direct evidence of ecological changes as a result of Native American burning during the last 2100 years. Climate has influenced fire activity significantly over the past 2100 years. For example, the Medieval Climate Anomaly Period shows increased charcoal levels at Pothole Lake in steppe and decreased levels at Hedrick Pond at the forest/steppe ecotone. During the Little Ice Age, background CHAR decreased at Swan Lake in lodgepole pine forest and increased at Pothole Lake. These changes in charcoal levels suggest shifts in fuel conditions as a result of available moisture. During dry periods, steppe areas were more prone to burning and forested areas may have been fuel limited. During wet periods, fires in steppe regions increased with increasing available fuels, and fires in forested areas were suppressed due to increased fuel moisture. Particular fire events coincide with the appearance of Euro-Americans in Jackson Hole and may have been deliberately set. From these initial results, it is clear that climate has predominantly shaped the fire regimes of Grand Teton National Park over the last 2100 years.

\section{$\downarrow$ Literature Cited}

Agee, J.K. 1990. The historical role of fire in Pacific Northwest forests. In: Natural and prescribed fire in Pacific Northwest forests. J.D. Walstad, S.R. Radosevich, and D.V. Sandberg (eds). Oregon State University Press, Corvallis. p. 25-37.

Arno, S.F. and Sneck, K.M. 1977. Method for determining fire history in coniferous forests of the mountain west. USDA Forest Service Research Paper INT-RP-481.

Baker, W.L. and Ehle, D. 2001. Uncertainty in surface fire history: the case of ponderosa pine forests in the western United States. Canadian Journal of Forest Research 31: 1205-1226.

Bradley, R.S. 1999. Paleoclimatology: Reconstructing Climates of the Quaternary. Second Edition. Harcourt Academic Press, San Diego. 
Connor, M.A. 1998. Final Report on the Jackson Lake Archaeological Project, Grand Reclamation Pacific Northwest Office, Boise, ID

Cook, E.R., D.M. Meko, D.W. Stahle, M.K. Cleaveland. 1999. Drought reconstructions for the continental United States. Journal of Climate 12: 1145-1162.

Daugherty, J. 1999. A Place Called Jackson Hole: A Historic Resource Study of Grand Teton National Park. Grand Teton Natural History Association, Moose, WY.

Dean Jr., W.E. 1974. Determination of carbonate and organic matter in calcareous sediments by loss on ignition: comparison to other methods. Journal of Sedimentary Petrology 44: 242-248.

Faegri K., J. Iverson, P.E. Kaland and K. Krzywinski. 1989. Textbookof Pollen Analysis. John Wiley, New York.

Hughes, M.K. and H.F. Diaz. 1994. Was there a 'Medieval Warm Period', and if so, where and when? Climatic Change 26: 109-142.

Johnson, E.A. and S.L. Gutsell. 1994. Fire frequency models, methods and interpretations. Advanced Ecological Research 25: 214-220.

Long, C.J., C. Whitlock, P.J. Bartlein and S.H. Millspaugh. 1998. A 9000-year fire history from the Oregon Coast Range, based on a high-resolution charcoal study. Canadian Journal of Forestry 28: 774-787.

Loope, L.L. 1974. Fire History Investigations in Grand Teton National Park. Unpublished agency report. 22pp.

Marlon, J., P.J. Bartlein and C. Whitlock. Fire-fuelclimate linkages in the northwestern U.S. during the Holocene. The Holocene. In Press.

McKenzie, D., Z. Gedalof, D.L. Peterson and P. Mote. 2004. Climatic change, wildfire and conservation. Conservation Biology 18(4): 890-902.

Meyer, G. A., S.G. Wells and A.J.T. Jull. 1995. /Fire and alluvial chronology in Yellowstone
National Park: Climatic and intrinsic controls on Holocene geomorphic processes GSA Bulletin 107(10):1211-1230.

Millspaugh, S., C. Whitlock, P.J. Bartlein. 2004. Postglacial fire, vegetation, and climate history of the Yellowstone-Lamar and Central Plateau provinces, Yellowstone National Park. In: Linda L. Wallace (ed.) After the Fires: The Ecology of Change in Yellowstone National Park. Yale University Press, New Haven and London.

Swetnam, T.W. 2002. Fire and climate history in the Western Americas from tree rings. PAGES News 10(1): 6-8.

Swetnam, T.W.and J.L. Betancourt. 1998. Mesoscale disturbance and ecological response to decadal climatic variability in the American Southwest. Journal of Climate 11,31283147.

Stuiver M., P.J. Reimer and T.F.Braziunas. 1998. High-precision radiocarbon age calibration for terrestrial and marine samples. Radiocarbon 40: 1127-51.

Thompson, R. and F. Oldfield. 1986. Environmental Magnetism. Allen \& Unwin, London.

Whitlock, C. 1993. Postglacial vegetation and climate of Grand Teton and southern Yellowstone National Parks. Ecological Monographs 63(2): 173-198.

Whitlock, C. and P.J. Bartlein. 1993. Spatial variations of Holocene climatic change in the Yellowstone region. Quaternary Research 39: 231-238.

Whitlock, C., P.J.Bartlein and K. Van Norman. 1995. Stability of Holocene climate regimes in the Yellowstone region. Quaternary Research 43(3): 433-436.

Whitlock, C. and C. Larsen. 2001. Charcoal as a fire proxy. In: J.P. Smol, H.J.B. Birks, W.M. Last (eds.) Tracking Environmental Change Using Lake Sediments. Volume 3: Terrestrial, Algal, and Siliceous Indicators. Kluwer Academic Publishers, Dordrecht, The Netherlands. p. 75-97. 
Whitlock C., S.L. Shafer and J. Marlon . 2003- "The role of climate and vegetation change in shaping past and future fire regimes in the northwestern US and the implications for ecosystem management". Forest ecology and management (0378-1127), 178 (1-2), p. 5 .

Whitlock, C., M.M. Bianchi' P.J. Bartlein, V. Markgraf, J. Marlon, M. Walsh and N. McCoy. 2006. Postglacial vegetation, climate, and fire history along the east side of the Andes (lat $41-42.5^{\circ} \mathrm{S}$ ), Argentina.

Quaternary Research 66:2. 187-201 